\title{
Combining ability between common bean gene groups for root distribution trait
}

\author{
Capacidade de combinação entre grupos gênicos de feijão para característica \\ distribuição radicular
}

\author{
${\text { Paulo Henrique Cerutti }{ }^{* *} \text { (D), Sibila Grigolo }}^{1}$ (D), Rita Carolina de Melo' (D), Ana Carolina da Costa Lara Fioreze ${ }^{2}$ (D), \\ Altamir Frederico Guidolin ${ }^{1}$ (D), Jefferson Luís Meirelles Coimbra' ${ }^{1}$
}

${ }^{1}$ Universidade do Estado de Santa Catarina/UDESC, Lages, SC, Brasil

2Universidade Federal de Santa Catarina/UFSC, Curitibanos, SC, Brasil

*Corresponding author: paulohcerutti@gmail.com

Received in March 5, 2020 and approved in July 17, 2020

\begin{abstract}
When different gene groups are combined by hybridization, the expression of predominant genes for a trait must be known. This understanding is fundamental to the decisions made by breeders in the stages of cultivation and selection of segregating populations during the breeding program. Thus, the objective of this study was to determine the effects of combining ability and gene action for the root distribution traits of the Andean and Mesoamerican common bean gene groups. Six common bean parents from the Andean and Mesoamerican groups were hybridized in a complete diallel mating scheme, resulting in $30 F_{1}$ hybrids. The parents and hybrids were planted in the field in a simple lattice design. The target trait was root distribution, calculated as the relative number of roots in the topsoil. The effect of the general combining ability was significantly higher than that of the specific combining ability (58\%) and the reciprocal effect (41\%). Particularly, the combination estimates were modified according to the order of the gene groups used. The combinations IPR Uirapuru x BAF53 (Mesoamerican x Andean), BAF53 x CBS14 (Andean $x$ Andean), and CBS14 x IPR Uirapuru (Andean x Mesoamerican) mainly exhibited an increase in the mean root distribution. However, the highest fraction of genetic variance correlated with additive components (60\%), even in crosses involving different gene groups. Consequently, the additive gene action was predominant in the expression of root distribution trait in common bean, irrespective of the gene group used.
\end{abstract}

Index terms: Gene action; andean and mesoamerican gene pool; diallel analysis.

\begin{abstract}
RESUMO
Quando combinados distintos grupos gênicos por meio de hibridações, é necessário o conhecimento do tipo de ação gênica preponderante na expressão de um caráter. O entendimento dessa informação ampara melhoristas para a tomada de decisões nas etapas de condução e seleção de populações segregantes no decorrer do programa de melhoramento genético. Assim, o objetivo do trabalho foi determinar os efeitos da capacidade de combinação e ação gênica para a característica distribuição radicular dos grupos de feijão Andino e Mesoamericano. Seis genitores de feijão dos grupos andino e mesoamericano foram hibridados em esquema de dialelo completo, resultando em 30 híbridos $\mathrm{F}_{1}$. Os genitores e híbridos foram conduzidos a campo em delineamento látice simples. A característica alvo foi a distribuição das raízes, calculada como a quantidade relativa de raízes no solo superior. 0 efeito da capacidade geral de combinação foi significativamente maior em relação aos efeitos de capacidade específica de combinação (58\%) e efeito recíproco (41\%). As estimativas de combinações foram modificadas em função da ordem dos grupos gênicos utilizados. As combinações IPR Uirapuru x BAF53 (mesoamericano $x$ andino), BAF53 x CBS14 (andino $x$ andino) e CBS14 x IPR Uirapuru (andino $x$ mesoamericano) foram as principais responsáveis por incrementar a média da característica distribuição radicular. No entanto, mesmo que realizando combinações entre grupos gênicos, a maior fração da variância genética foi relacionada a componentes aditivos (60\%). Consequentemente, a ação gênica aditiva foi predominante na expressão do caráter distribuição radicular em feijão independente do grupo gênico utilizado.
\end{abstract}

Termos para indexação: Ação gênica; pool gênico andino e mesoamericano; análise dialélica. 


\section{INTRODUCTION}

Common bean (Phaseolus vulgaris L.) is an important protein-rich food, mainly consumed in Latin American countries and across the African continent (Polania et al., 2016). However, approximately $60 \%$ of the global output is produced in water-stressed environments. The primary reasons for the incomplete exploitation of the yield potential of cultivars developed in plant breeding programs include water deficiency aggravated by disease attacks (Atkinson; Urwin, 2012; Ribeiro et al., 2019). Therefore, the breeding of genotypes capable of thriving under heterogeneous soil-climatic conditions could improve the tolerance of these cultivars to water stress. Traits related to the root system are directly associated with the ability of resource acquisition under non-optimal cultivation conditions (Basu; Pal, 2011). However, only a few breeding programs have focused on an improved root system of genotypes grown in the field.

The existence of genetic variability in traits related to the root system may be associated with higher genotypic adaptability even to adverse cultivation conditions (Mayor-Duran; Raatz; Blair, 2016). With an aim to the development of superior genotypes, breeders should exploit allelic sources of different gene groups (Beebe et al., 2008). The common bean has two main gene pools. The Mesoamerican gene pool is characterized by smallseeded plants with deep-reaching root development, and the Andean gene pool has large-seeded plants and a greater root concentration in the surface layers (Beebe et al., 2013). The seeds of the gene groups also differ in size and coat color, and in the phaseolin-protein types contained in grains (Polania et al., 2016). The Mesoamerican group predominantly contains genotypes with growth habits type II (indeterminate shrub growth) and type III (indeterminate prostrate growth), while the Andean group predominantly contains growth habit type I (determinate growth) and type IV (indeterminate climbing growth) (Singh; Gepts; Debouck, 1991; Nienhuis; Singh, 1988; Kwak et al., 2012).

The interbreeding between gene groups may result in complementary traits related to the selection of target and thus results in hybrid populations with phenotypic values of the root system that exceed the parental means (Rieseberg; Archer; Wayne, 1999; Mayor-Duran; Raatz; Blair, 2016). Accordingly, diallel crosses are routinely used in breeding programs (Catarina et al., 2019). Mating systems such as diallel crosses provide information about the genetic component (gene action) predominantly responsible for trait expression and estimates of the general combining ability (GCA), specific combining ability
(SCA), and reciprocal effects (REC) (Griffing, 1956; Vencovsky; Barriga, 1992). Further, the scheme enables a performance prediction of the hybrid population based on parent performance (Baker, 1978).

Breeding strategies depend on the gene action that influences a trait; therefore, this information can help decision-makers to conduct hybridizations and guide the cultivation and selection processes of segregating populations more effectively (Oghan et al., 2018). Thus, the objective of this study was to determine the effects of combining ability and gene action for the root distribution trait of the Andean and Mesoamerican common bean gene groups.

\section{MATERIAL AND METHODS}

The experiments were carried out in a research area of the Instituto de Melhoramento e Genética Molecular (IMEGEM) of the Universidade do Estado de Santa Catarina (UDESC), at the Center for Agricultural Sciences (UDESC/CAV), in Lages, Santa Catarina $\left(27^{\circ} 47^{\prime} \mathrm{S}, 50^{\circ} 18^{\prime} \mathrm{W}, 930 \mathrm{~m}\right.$ asl). According to the Köppen classification, the climate there is $\mathrm{Cfb}$ (humid temperate mesothermal), with mild summers (Pandolfo et al., 2002). Initially, six common bean parents (BAF07, BAF35, IPR Uirapuru, BAF53, CBS14, BRS Embaixador) were hybridized in a complete diallel cross, with $\mathrm{n}^{2}$ combinations, $n(n-1) / 2$ hybrid populations and $n(n-1) / 2$ reciprocal populations, where $\mathrm{n}$ is the number of parents.

Table 1 lists the traits of the parents used in the diallel cross. Parents with contrasting traits were chosen based on the genetic value of each parent for the root distribution trait determined in previous experiments.

The parent plants were sown in 4-L pots filled with commercial substrate and grown in a greenhouse. Sowing of the genotypes was staggered to prolong the flowering period and favor the growth of flower buds appropriate for hybridization. Hybridization was performed by bud emasculation based on the methodology of Vieira (1967) and resulted in 30 hybrids.

The field performance of parents, hybrids, and reciprocal was evaluated in the 2017/2018 growing season in an experiment with a partially balanced simple lattice design. The soil of the experimental area was of Inceptisol Udepts Humudepts, clayey texture. The chemical properties determined by soil analysis were clay $=34 \%, \mathrm{pH}=5.9$, $\mathrm{K}=80 \mathrm{mg} \mathrm{dm}^{-3}, \mathrm{P}=10.05 \mathrm{mg} \mathrm{dm}^{-3}$, and organic matter = $2.7 \%$. During the crop cycle, all fertilization practices were according to the technical recommendations for common bean cultivation (CQFS-RS/SC, 2016). 
Table 1: Traits of the six parents used for a diallel cross among common bean gene groups.

\begin{tabular}{ccccc}
\hline Parent & Market group & Gene group & Growth habit* & Origin \\
\hline BAF07 & Black & Mesoamerican & III & Accession $^{1}$ \\
BAF35 & Carioca & Mesoamerican & III & Accession $^{1}$ \\
IPR Uirapuru & Black & Mesoamerican & II & Cultivar $^{1}$ \\
BAF53 & Color (cream) & Andean & $\mathrm{I}$ & Accession $^{1}$ \\
CBS14 & Color (white) & Andean & $\mathrm{I}$ & Accession $^{2}$ \\
BRS Embaixador & Color (red) & Andean & $\mathrm{I}$ & Cultivar $^{2}$ \\
\hline
\end{tabular}

* I: determinate growth habit, upright; II: indeterminate, upright growth habit; III: indeterminate, semi-upright to prostate growth habit. CAV/UDESC germplasm bank accessions; ${ }^{2}$ Accession of the Universidade Federal de Santa Catarina (UFSC).

Each experimental unit consisted of three 2-m rows spaced $0.5 \mathrm{~m}$ apart. In the border rows of each experimental unit, the sowing density was two seeds per meter. Such density lower than that of commercial crops is required to facilitate the proper evaluation of root distribution. The phenotypic traits of two plants per plot were characterized by the methodology proposed by Bohm (1979), with slight modifications. Evaluations were performed when 50\% +1 plants per plot were fully flowering. For this, trenches were dug perpendicular to the sowing line. After opening the profile, the roots were exposed by pointed sticks. Thereafter, a rectangular frame (width $0.50 \mathrm{~m} \times$ depth 0.30 $\mathrm{m}$, forming 60 grid squares with $0.05 \mathrm{~m}$ sides) was placed within the profile. The installation (profile/frame) was photographed from a distance of $0.60 \mathrm{~m}$. Each picture was evaluated in the laboratory for the presence (1) or absence (0) of roots in each grid. Subsequently, the presence of roots in each picture was expressed in percentage (total presence in the grids $/ 60) * 100$.

The combining abilities were estimated by the method proposed by Griffing (1956), represented by the model: $\mathrm{Y}_{\mathrm{ij}}=\mathrm{m}+\mathrm{g}_{\mathrm{i}}+\mathrm{g}_{\mathrm{j}}+\mathrm{s}_{\mathrm{ij}}+\mathrm{r}_{\mathrm{ij}}+\varepsilon_{\mathrm{ij}}$. Where $\mathrm{Y}_{\mathrm{ij}}$ : the mean value of the hybrid combination or of each parent; $\mathrm{m}$ : the overall test mean; $g_{i}$ and $g_{j}$ : effects of each general combining ability (i-th, $\mathrm{j}$-th parent); $\mathrm{s}_{\mathrm{ij}}$ : effect of specific combining ability for hybridizations between parents $i$ and $\mathrm{j} ; \mathrm{r}_{\mathrm{ij}}$ : the reciprocal effect that measures the differences provided by the parent $\mathrm{i}$ or $\mathrm{j}$, when used as a male or female in hybridization ij (this component was partitioned in maternal $(\hat{m} i j)$ and nonmaternal ( $\hat{n} i j)$ effects), and $\varepsilon_{\mathrm{ij}}$ : experimental error associated with observations (Zang; Kang, 1997; Cruz; Regazzi; Carneiro, 2012). The software DIALLEL-SAS05 macro was used for analyses of the results (Zhang; Kang; Lamkey, 2005). Due to plot losses, the estimated effects of each component and the sum of squares were calculated by the least square method, using equations derived from the model $\mathrm{Y}=\mathrm{X} \beta+\varepsilon$, where $\mathrm{Y}$ : is the mean vector for treatment effects, $\mathrm{X}$ : constant matrix defined by the genetic model, $\beta$ : vector of unknown parameters, and $\varepsilon$ : errors associated with means (Vencovsky; Barriga, 1992). These estimates can be obtained by the IML procedure (interactive matrix programming language). The additive genetic value in percent was computed by the mean square relation of the combining abilities (GCA)/ (GCA + SCA). The means of trait root distribution were compared by mean comparison contrasts, using the glm (general linear model) procedure. All analyses were performed using the SAS University software.

\section{RESULTS AND DISCUSSION}

The experimental coefficient of variation was $13.75 \%$ and the determination coefficient was 0.72 (Table 2). Low CV estimates indicate that the trait is a little affected by environmental variations and exhibits good accuracy of the trial estimates. High $\mathrm{R}^{2}$ values indicate the adequacy of the mathematical model to explain the causes of variation and that most of the mean performance detected for the dependent variable is explained by the factors controlled in the experiment. The use of the lattice design was confirmed due to its high experimental robustness to establish adequate $\mathrm{CV}$ and $\mathrm{R}^{2}$ estimates.

The significance of the genotype mean square was estimated by the $F$ test $(p<0.05)$ for root distribution (Table 2) and indicates the existence of variability among the 35 evaluated genotypes, the presence of genetic diversity between parents and their combinations, and confirms the use of contrasting genotypes in diallel mating systems (Bekeko et al., 2018). The parents used in making the diallel analysis are contrasted with each other for the market group, growth habit, and gene group. The crossing of parents with more contrasting traits possibly resulted in few hybrid combinations with the superior mean to the parents. For future breeding processes, diversity 
between genotypes is a prerequisite for the identification of ideotypes (Mayor-Duran; Raatz; Blair, 2016; Catarina et al., 2019). Once the segregating populations resulting from targeted hybridization are established, knowledge about how the trait is inherited is needed for the cultivation and selection of superior populations. The success of this selection is proportional to the degree of genetic diversity among the lines and depends on the additive gene effects (Ramalho; Santos; Zimmermann, 1993).

The sum of squares of genotypes was initially partitioned into the effects of parents, hybrids, and parenthybrid by contrasts (Table 2 ). This partitioning was carried out to observe the range of variation (mean squares) of the parents and hybrids. The highest percentage of variation was attributed to the hybrid*parent contrast. Although the gene action has a purely additive nature, besides, in this case, the phenotypic mean of the progenies assumed a value equal to that of the parents, few hybrid combinations exhibited a mean superior to that of their parents, favoring the greatest contrast effect between hybrids and parents. Simply put, one or more combinations had an above-average performance, possibly increasing the mean root distribution. The genotype effect was also partitioned into general combining ability (GCA), specific combining ability (SCA), and reciprocal effect (REC) (Table 2). The significance of the GCA effect shows that at least one of the six lines had a mean performance different from that of the other lines, in terms of concentration of favorable alleles for root distribution. The mean square of GCA was higher than that of SCA (58\%) and REC (41\%). The finding that GCA exceeded SCA and the reciprocal effect was consistent with the results reported elsewhere for autogamous crops such as soybean, and common bean (Rocha et al., 2014; Moura et al., 2018; Rocha; Pereira; Vello, 2018).

In crops with autogamous reproduction, the genotypes are generally selected in more advanced selection generations (predominance of homozygous loci). Unlike non-additive gene effects, in the case of predominantly additive gene effects, breeders can carry out the selection in earlier generations of breeding programs (Mukamuhirwa; Tusiime; Mukankusi, 2015). The results of this study indicated that the SCA had no significant effect (Table 2). The SCA reflects the contribution of all non-additive effects on trait expression (Menon et al., 2015). In general, there was no remarkable degree of complementarity between the parents for allele frequencies in loci with some dominance. The non-significance of SCA led us to accept the hypothesis that direct hybrid combinations do not differ from each other (Ho: $\mathrm{s}_{12}=$ $\mathrm{s}_{13}=\ldots \mathrm{s}_{56}=0$ ) for root distribution. Further, in the absence of dominance, SCA does not indicate significance, and the reciprocal effect is not valid, i.e., SCA is conditioned by all non-additive effects, such as overdominance and epistasis (Vencovsky; Barriga, 1992).

Table 2: Diallelic variance analysis for a complete diallel involving six bean parents and their respective hybrid populations, considering the root distribution trait.

\begin{tabular}{|c|c|c|}
\hline Source of variation & Degree of freedom & Mean square \\
\hline Genotypes & (34) & $174.44^{*}$ \\
\hline Parents & 5 & 36.53 \\
\hline Hybrid & 28 & $196.26 *$ \\
\hline Hybrid vs. Parents & 1 & 252.91 * \\
\hline Genotypes & (34) & $174.44^{*}$ \\
\hline $\mathrm{GCA}^{1}$ & 5 & $229.36 *$ \\
\hline $\mathrm{SCA}^{2}$ & 14 & 144.69 \\
\hline $\mathrm{REC}^{3}$ & 15 & $171.40 *$ \\
\hline MATE $^{4}$ & 5 & 36.59 \\
\hline NMATE $^{5}$ & 10 & $225.72 *$ \\
\hline Residue & 35 & 72.51 \\
\hline Total & 69 & \\
\hline O Mean ${ }^{6}: 61.90 \%$ & P mean7: 66.08\% & $\operatorname{AGE}^{9}(\%): 60.0$ \\
\hline $\mathrm{R}^{2(10):} 0.72$ & $C^{11}: 13.75$ & $\sigma_{\mathrm{g}}^{2}{ }^{13}: 48.88$ \\
\hline
\end{tabular}


The non-significance of the SCA reflects the low contribution of non-additive effects on the expression of root distribution trait. This fact can explain the significant effect of GCA, indicating that the genetic control of root distribution in common bean possibly is predominantly additive in nature. It should be noted that the analysis of variance is comprehensive in nature. Significant effects can be found for each hybrid combination in tests for significance because the SCA reflects a deviation of the hybrid from the expected, based on the GCA of the parents involved. The predominance of additive gene effects for plant architecture-related traits have been studied in wheat (Gowda et al., 2012), in common bean (Moura et al., 2018), and in hybridizations between Andean and Mesoamerican common bean gene groups (Mukankusi et al., 2011). The predominance of additive effects on root distribution in common bean was also reported (Melo et al., 2016). On the other hand, several authors emphasize the significance, and in some situations even the predominance of non-additive gene type in the genetic control of one or more traits, such as root distribution, resistance to Fusarium, resistance to gray leaf spot, days to flowering, seed yield, pods per plant, and grain yield (Toaldo et al., 2013; Batista et al., 2017; Bekeko et al., 2018; Oghan et al., 2018; Rocha; Pereira; Vello, 2018).

For the REC, significance was observed for root distribution (Table 2). Estimates of REC can be attributed to inheritance arising from the cytoplasm, maternal effects, or sex linkage (Kaushik; Puri, 1984). In this study, the nonmaternal effect was significant. While the maternal effect is related to cytoplasmic genetic factors, the non-maternal effect is attributed to the interaction between nuclear genes with the effects of cytoplasmic genes (Singh et al., 2017). Significant RECs were also reported earlier for growth and reproductive traits in common bean genotypes of the same gene group (Baldissera et al., 2012; Rocha et al., 2014; Singh et al., 2017).

The additive genetic effect (AGE) for root distribution was $60 \%$ (Table 2). Gurmu, Hussein, and Laing, (2018) reported mean additive values of $68 \%$ in postharvest tomato traits. Likewise, Rocha et al. (2014) observed a mean value of $80 \%$ for grain yield components in common bean. The interpretation of the percentage shows that most of the genetic variation in the diallel analysis was due to additive gene effects. Another way of representing the hegemony of the additive genetic component is by the direct GCA/SCA ratio, also called predominant gene action. In this study, we observed a ratio of 1.59 , i.e., a ratio of approximately $1.6: 1$, indicating that the additive component of trait expression is 1.6 times higher than that of the non-additive components. The authors Mukankusi et al. (2011) cited a value of 0.92 for Fusarium wilt resistance in common bean. This information shows that the predominant gene activity is directly associated with the degree of complementarity of the parents, the target trait of the breeding program, and the mode of reproduction of the crop (Allard, 1971).

Assuming that breeding strategies are largely influenced by the action of the predominant type of genes, and a greater contribution of genetic variance of additive nature indicates the possibility of genetic gain for the populations, enhancing the chances for successful selection (Bekeko et al., 2018). The analysis showed that the predominance of additive components associated with root distribution, and the performance of segregating populations, based on the GCA of the parents becomes predictable. Accordingly, the selection of plants with superior agronomic traits may result in progenies that also perform better, because the phenotypic performance continues over generations (Gurmu; Hussein; Laing, 2018).

Another important estimate is the proportion of phenotypic variation exclusively due to genetic components. High values of heritability coefficient $\left(h^{2}\right)$ indicate an association with additive genetic variance, a lower environmental variation, and lower effect of genotype-environment interaction (Fehr, 1987). The inverse relationship and predominance of environmental effects on a given trait indicate a low or zero selection efficiency (Tasisa et al., 2018). In this study, the coefficient of broad-sense heritability for root distribution was 0.40 (Table 2). The value of $40 \%$ indicates that the selection of superior genotypes for root distribution may be successful. Thus, because the value is considered moderate, a larger number of plants must be evaluated, and a less rigorous selection process must also be considered. Thus, the availability of heritability estimates is crucial for decisions about subsequent stages of plant breeding, e.g., direct or indirect selection, the breeding method, and selection intensity used in segregating populations (Oghan et al., 2018).

The heritability coefficient is directly related to the phenotype/genotype correlation estimates and selection gain. We estimated the phenotype/genotype (COV Ph, $\mathrm{G})$ covariance, which is equal to $\sigma^{2} \mathrm{~g}$ (genetic variance), as pointed out and exemplified by Vencovsky and Barriga (1992). The COV Ph, G value for root distribution was 48.88 (Table 2). Thus, the $\sigma^{2} \mathrm{~g}$ value indicates the purely genetic component of the treatments and indicates the extent of transfer of the genetic variation present in the 
parents to the progenies. The $\sigma^{2} \mathrm{~g}$ values of the Andean and Mesoamerican common bean genotypes were also reported for days of flowering (3.49), days of maturation (1.46), number of nodes per stem (1.37), number of grains per pod (16.38), number of pods per plant (1.43), and 100-grain weight (15.19) (Santos et al., 2015). The high genetic variability suggests the possibility of effective selection in the development of superior genotypes (Correa et al., 2003). The situation in which the phenotype/ genotype covariance is equal to $\sigma^{2}$ g makes it possible to predict the genetic gain because the heritability coefficient is determined by $\sigma^{2} \mathrm{~g}$, the genetic variation component (Vencovsky; Barriga, 1992). The covariance between selected plants and their descendants is fundamental for the success of selection; the higher the covariance value $(\mathrm{Ph}, \mathrm{G})$, the more effective is the process.

In view of the significance and predominance of additive effects, it is recommended to estimate the combining ability of each parent used. Of these estimates, $34 \%$ were significant, according to the t-test $(\mathrm{p}<0.05)$ (Table 3$)$. The effects of GCA determine the mean performance of each parent compared to the other parents in other mating blocks, indicating that the $g_{i}$ estimate corresponds to the genetic value of the individual plant in question.

Table 3: Estimates of the general combining ability $\left(\hat{g}_{i}\right)$ for root distribution in a diallel with six common bean parents.

\begin{tabular}{cc}
\hline Parents & $\hat{g}_{i}$ \\
\hline$----\cdot-104^{*}$ \\
BAF07 & 1.774 \\
BAF35 & -0.257 \\
IPR Uirapuru & -2.431 \\
CBS14 & $5.033^{*}$ \\
BAF53 & -0.013
\end{tabular}

* Significant at 5\% probability by the t-test.

Low $g_{i}$ estimates indicate that the intrinsic GCA of the parent is not different from the overall mean. However, if $g_{i}$ estimates are significant, the parent has a different (higher or lower) performance than the mean parent performance. Parents with high $\mathrm{g}_{\mathrm{i}}$ are usually preferred in breeding programs of autogamous plants, for facilitating the selection of homozygous lines (Cruz; Regazzi; Carneiro, 2012).
For Considering root distribution, the parents BAF53 (Andean), and BAF35 (Mesoamerican) had positive $g_{i}$ estimates. This shows the influence of gene groups on the $g_{i}$, because the positive and high values were inherited from the Andean parent BAF53, with a high and significant $g_{i}$ value (5.033) (Table 3). This parent can be considered a potential participant in hybridization steps in breeding programs focused on larger root distribution. The $\mathrm{g}_{\mathrm{i}}$ estimates of the parents BAF07, CBS14, IPR Uirapuru, and BRS Embaixador, however, were negative, with the lowest $g_{i}$ value (-4.104) exhibited by BAF07. Therefore, clearly, these parents used in mating blocks would probably not result in superior progenies for root distribution, because they promote a reduction of this trait.

According to Rocha, Pereira, and Vello (2018), parents with high and positive $\mathrm{g}_{\mathrm{i}}$ have a high concentration of favorable alleles for the target trait. The effects of positive and significant $g_{i}$ were also reported by Gurmu, Hussein, and Laing, (2018). The selection of parents with high $g_{i}$ values is fundamental in promoting increments in the target trait (Mukamuhirwa; Tusiime; Mukankusi, 2015). In this situation, genotypes with high estimates of general combining ability have a better capacity to acquire environmental (water and nutritional) resources under non-optimal cultivation conditions. Root distribution is a determinant of plants for their ability to explore heterogeneous soil conditions (Lynch; Brow, 2001; Ho et al., 2005). Genotype BAF53, for example, can promote root distribution increments of around 5\% in hybridizations, and consequently, the mean of grid squares with roots reaches $65 \%$, ensuring an efficient resource acquisition. According to this percentage, parent BAF35 can induce an increment of $1.8 \%$ and raise the mean to $63 \%$. However, the phenotypic mean of BAF07 could eventually sink to $59 \%$, i.e., the genotype would reduce root distribution and adaptation to adverse cultivation conditions in the progenies.

Among the established hybrid combinations $\left(\mathrm{s}_{\mathrm{ij}}\right), 50 \%$ exhibited positive estimates for root distribution, and $14 \%$ had a significant effect (Table 4). Moreover, in all combinations with a significant effect, parents of both gene groups (Andean vs. Mesoamerican or vice versa) are involved, highlighting the complementarity between them. Since the SCA estimates correspond to the superior or inferior performance of the direct hybrid in relation to the performance of its parents, high $s_{i j}$ estimates are considered ideal for root distribution breeding programs (Ramalho; Santos; Zimmermann, 1993). Nevertheless, combining two parents with high $g_{i}$ values may not result in the best hybrid. Consistently, Moura et al. (2018), observed that the significance of the established hybrid combinations was $16 \%$ for common bean grain yield. 

Table 4: Estimates of specific combining ability $\left(\hat{\mathrm{s}}_{\mathrm{ij}}\right)$ and reciprocal effect $\left(\hat{r}_{i j}\right)$ for root distribution, in a six-parent
diallel cross.

\begin{tabular}{|c|c|c|c|}
\hline Combinations & $\hat{\mathrm{S}}_{\mathrm{ij}}$ & Combinations & $\left(\hat{r}_{i j}\right)$ \\
\hline \multicolumn{4}{|c|}{ |- } \\
\hline BAF07 x IPR Uirapuru & 5.56 & IPR Uirapuru x BAF07 & 4.31 \\
\hline BAF35 x IPR Uirapuru & 3.43 & IPR Uirapuru x BAF35 & -4.48 \\
\hline \multicolumn{4}{|c|}{ - } \\
\hline BAF53 x CBS14 & 6.68 & CBS14 x BAF53 & 2.51 \\
\hline BAF53 x BRS Embaixador & 3.10 & BRS Embaixador x BAF53 & -1.47 \\
\hline CBS14 x BRS Embaixador & -10.32 & BRS Embaixador x CBS14 & 2.59 \\
\hline \multicolumn{4}{|c|}{ 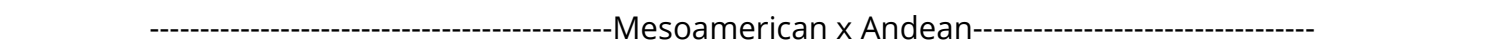 } \\
\hline BAF35 $\times$ BAF53 & -4.93 & BAF53 x BAF35 & -3.68 \\
\hline BAF35 x CBS14 & 9.55 & CBS14 x BAF35 & 2.47 \\
\hline BAF35 x BRS Embaixador & -6.68 & BRS Embaixador x BAF35 & 1.81 \\
\hline BAF07 $\times$ BAF53 & $-24.88 *$ & BAF53 $\times$ BAF07 & $5.94 *$ \\
\hline BAF07 x CBS14 & $-13.06 *$ & CBS14 x BAF07 & -7.89 \\
\hline BAF07 x BRS Embaixador & 3.94 & BRS Embaixador x BAF07 & 10.61 \\
\hline IPR Uirapuru x BAF53 & 10.97 & BAF53 x IPR Uirapuru & $-12.7^{*}$ \\
\hline IPR Uirapuru x CBS14 & -9.11 & CBS14 x IPR Uirapuru & $15.8^{*}$ \\
\hline IPR Uirapuru x BRS Embaixador & -6.02 & BRS Embaixador x IPR Uirapuru & -6.44 \\
\hline
\end{tabular}

* Significant at 5\% probability by the t-test.

The negative effects on root distribution were the highest when the hybrid combination originated from the cross between the Mesoamerican x Andean groups, for example, in the hybrids BAF07 x BAF53 and BAF07 $x$ CBS14, suggesting that the use of their parents in mating schemes could result in lines with a poor root distribution. Interestingly, in the hybrid combination BAF07 x BAF53 (distinct gene groups), the parents independently exhibited an antagonistic performance for $\mathrm{g}_{\mathrm{i}}$ (negative for BAF07 and positive for BAF53).

The negative and significant estimates can be explained by a possible incompatibility between the gene groups, as already reported in the literature (Beebe et al., 2013). Hybridizations involving both large and smallseeded parents can lead to "dwarfism" or "weakness" in the $F_{1}$ generation, negative heterosis, and poor performance in the $\mathrm{F}_{2}$ and subsequent generations. This is the outcome of unequal gene segregation (Nienhuis; Singh, 1988). The mean performance for these two hybrid combinations (46 and 54\%) was below the overall mean root percentage. Contrarily, the combinations BAF35 x CBS14 and IPR Uirapuru $x$ BAF53, with a root distribution of 68 and $69 \%$, exhibited improved traits. Promising segregating populations for root distribution can be obtained with high and positive $\mathrm{s}_{\mathrm{ij}}$ values.

The reciprocal effect $\left(r_{i j}\right)$ is used to indicate which parent holds promise when used as a pollen donor or recipient in hybridization schemes. The $\mathrm{r}_{\mathrm{ij}}$ estimates in this study indicated that $58 \%$ of the values were positive, and $22 \%$ were significant by the t-test $(p<0.05)$ (Table 4$)$. The combinations BAF53 x BAF07, and CBS14 x IPR Uirapuru increased the root percentage by 6 and $16 \%$ and raised the overall mean to $65 \%$ and $72 \%$, respectively for root distribution. Here we observe an inverse association, in which the combination of two gene groups in reciprocal crosses (BAF53 x BAF07) promoted increments in root distribution over BAF07 x BAF53 (direct combination $\mathrm{s}_{\mathrm{ij}}$ ).

Based on SCA and REC of the combinations BAF07 x BAF53 $\left(\mathrm{s}_{\mathrm{ij}}=-24.88\right)$. and CBS14 x IPR Uirapuru $\left(r_{i j}=15.88\right)$, these direct and reciprocal hybrids exhibited the highest genetic variation in relation to their parents. Consequently, they may be responsible for the highest mean square estimate for the hybrid effect in Table 2. Clearly, the progeny resulting from hybridization of BAF53 and BAF07, exhibited positive and significant $r_{i j}$ value $\left(r_{i j}=5.94\right)$, reinforcing the importance of defining 
the order of the parent in the hybridization stage. However, the highest positive gain in trait expression was observed in the Andean x Mesoamerican combination (for example, in CBS14 and IPR Uirapuru). This fact can be explained by the contrasting gene group and the contrasting traits, e.g., seed coat color and growth habit, of the parents involved. The results indicate that common bean genotypes with indeterminate growth habit have a greater root distribution than genotypes with a determinate growth habit (Velho et al., 2018).

It is also noteworthy that out of $50 \%$ of the combinations listed in Table 4, the use of parents in the maternal or paternal function causes no change in the sign ( + or - ) of the $r_{i j}$ estimates, but affects the magnitude of the estimates. The combination BAF53 x IPR Uirapuru also provides relevant information. When BAF53 was used as a female parent, the mean root distribution decreased to $54 \%\left(\mathrm{r}_{\mathrm{ij}}=-12.77\right)$, and when used as a male parent, it increased to $69 \%\left(\mathrm{~s}_{\mathrm{ij}}=10.97\right)$. Thus, when trying to increase root distribution, BAF53 should be used as a male parent. Singh et al. (2017) stated the importance of the parent order in hybridizations between Creole genotypes and a wild accession, of both of the Andean group; $F_{1}$ originating from the Creole parent as the mother had a longer root length than the reciprocal plants.

To explore the possible effects of hybrid vigor, the comparisons of hybrid (direct and reciprocal) means compared to the parents indicated significant differences by the t-test $(\mathrm{p}<0.05)$ for five progenies, with positive and negative heterosis (Table 5). Hybrid BAF07 x BAF53 had significant and negative heterosis, which may indicate a dramatic reduction in the mean root distribution of this hybrid combination. Consequently, the resource uptake capacity of this progeny may be reduced. The heterosis of combination CBS14 $x$ IPR Uirapuru was positive, with a mean root percentage of $82.5 \%$.
Although the exploitation of heterosis in autogamous plants is not very common, the understanding of hybrid vigor is essential, because selections that are inadequate or masked by the environmental effects in early breeding stages may fail to establish agronomically superior genotypes. Combinations between Andean and Mesoamerican genotypes, addressing morphological and physiological traits, can potentiate the development of common bean cultivars with enhanced water-stress tolerance. There are earlier reports of identification of lines with some degree of drought tolerance in the Mesoamerican group (Polania et al., 2016).

In this study, we discussed the selection of parents for the construction of the diallel to the estimation of the combining abilities, gene action and superiority of progenies in relation to the parents, and the predominance of additive gene effects. This fact may be related to the genetic similarity of parents among and within the gene groups for root distribution trait. Further, the information on the existence of additive genetic variance, together with the estimate of heritability coefficient and $\sigma^{2} g$ suggests the possibility of selection gains.

The selection of common bean genotypes with a well-developed root distribution, capable of exploring different soil layers in search of resources, is a workintensive and costly process. The selection process is hampered by the efforts required for phenotyping in the field and the influence of the environment on trait expression (Miguel et al., 2013). However, hybrid combinations with a significant effect and at least one parent with a significant GCA may possibly result in lines with improved root distribution. In addition, since root distribution is predominantly controlled by additive variance, early selection may be an option for breeding programs focusing on this trait.

Table 5: Estimated mean comparison of the percentage of root distribution between the respective hybrid combinations and the parent value.

\begin{tabular}{ccccccc}
\hline I $^{*}$ & BAF07 & BAF35 & IPR Uira. & BAF53 & CBS14 & BRS Emb. \\
\hline BAF07 & - & - & 1.25 & $-34.16^{*}$ & $-17.87^{*}$ & -5.41 \\
BAF35 & 3.36 & - & 4.86 & -8.47 & 10.48 & -10.30 \\
IPR Uira1 & -0.002 & -3.05 & - & 6.66 & -8.95 & -10.41 \\
BAF53 & -3.33 & -7.22 & $-17.08^{*}$ & - & 1.87 & -6.25 \\
CBS14 & -12.70 & 3.40 & $16.04^{*}$ & -2.29 & - & $-15.20^{*}$ \\
BRS Emb ${ }^{2}$. & -8.75 & -1.80 & -10.84 & -10.80 & -2.29 & - \\
\hline
\end{tabular}

*Significant at 5\% probability by the t-test. IIPR Uirapuru; ${ }^{2}$ BRS Embaixador. 


\section{CONCLUSIONS}

The prevalence of estimates due to general combining ability over specific combining ability revealed an additive effect of the genetic component with the greatest contribution to root distribution. The hybrid combination CBS14 x IPR Uirapuru (Andean $\mathrm{x}$ Mesoamerican gene groups) presented greater potential to increase the mean root distribution. The parents BAF53 and CBS 14 (Andean group), when used as mother parents, increased root distribution in the hybridization stages.

\section{ACKNOWLEDGEMENTS}

We are indebted to the Brazilian Federal Agency for Support and Evaluation of Graduate Education (CAPES), the National Council for Scientific and Technological Development (CNPq) and the Foundation for the Support of Scientific and Technological Research of Santa Catarina (FAPESC), for intellectual and financial support.

\section{REFERENCES}

ALLARD, R. W. Princípios do melhoramento genético de plantas. São Paulo: Edgard Blucher, 1971. 381 p.

ATKINSON, N, J.; URWIN, P, E. The interaction of plant biotic and abiotic stresses: From genes to the field. Journal of experimental botany, 63(10):3523-3543, 2012.

BAKER, R. J. Issues in diallel analysis. Crop Science, 18(4):533536, 1978.

BALDISSERA, J. D. C. et al. Capacidade combinatória e efeito recíproco em características agronômicas do feijão. Semina: Ciências Agrárias, 33(2):471-479, 2012.

BASU, P.; PAL, A. Spatio-temporal analysis of development of basal roots of common bean (Phaseolus vulgaris L.). Plant Signaling \& Behavior, 6(7):982-985, 2011.

BATISTA, R. O. et al. Inheritance of resistance to fusarium wilt in common bean. Euphytica, 213(7):133, 2017.

BEEBE, S. et al. Phenotyping common beans for adaptation to drought. Frontiers in Physiology, 4(35):1-20, 2013.

$\mathrm{BEEBE}$, S. et al. Selection for drought resistance in common bean also improves yield in phosphorus limited and favorable environments. Crop Science, 48(2):582-598, 2008 .

BEKEKO, Z. et al. Combining ability and nature of gene action in maize (Zea mays L.) inbred lines for resistance to gray leaf spot disease (Cercospora zeae-maydis) in Ethiopia. Crop Protection, 112:39-48, 2018.
BOHM, W. Methods of studying root systems. Berlin: Springer, 1979. 188p.

CATARINA, R. S. et al. Combining ability for fruit yield and quality in papaya recombinant inbred lines from the sexual conversion backcrossing. Euphytica, 215(10):1-10, 2019.

COMISSÃO DE QUÍMICA E FERTILIDADE DO SOLO CQFS-RS/SC RS/SC. Manual de calagem e adubação para os Estados do Rio Grande do Sul e de Santa Catarina. Sociedade Brasileira de Ciência do Solo. 2016. 376p.

CORREA, A. M. et al. Estimates of genetic parameters in common bean genotypes. Crop Breeding and Applied Biotechnology, 3(3):223-230, 2003.

CRUZ, C. D.; REGAZZI, A. J.; CARNEIRO, P. C. S. Modelos biométricos aplicados ao melhoramento genético. 4 . ed. Viçosa: UFV, 2012. 514p.

FEHR, W. R. Principles of cultivar development. New York: Macmillan, 1987. 536p.

GOWDA, M. et al. Relevance of specific versus general combining ability in winter wheat. Crop Science, 52(6):2494-2500, 2012.

GRIFFING, B. Concept of general and specific combining ability in relation to diallel crossing systems. Australian Journal of Biological Science, 9(4):463-493, 1956.

GURMU, F.; HUSSEIN, S.; LAING, M. Combining ability, heterosis, and heritability of storage root dry matter, beta-carotene and yield-related traits in sweetpotato. HortScience, 53(2):167-175, 2018.

HO, M. D. et al. Root architectural tradeoffs for water and phosphorus acquisition. Functional plant biology, 32(8):737-748, 2005.

KAUSHIK, L. S.; PURI, P. D. A study of maternal and maternal interaction effects in diallel crosses. Biometrical Journal, 26(7):771-777, 1984.

KWAK, M. et al. Multiple origins of the determinate growth habit in domesticated common bean (Phaseolus vulgaris). Annals of Botany, 110(8):1573-1580, 2012.

LYNCH, J. P.; BROWN, K. M. Topsoil foraging-an architectural adaptation of plants to low phosphorus availability. Plant and Soil, 237(2):225-237, 2001.

MAYOR-DURAN, V. M.; RAATZ, B.; BLAIR, M. W. Desarrollo de líneas de frijol (Phaseolus vulgaris L.) tolerante a sequía a partir de cruces inter acervo con genotipos procedentes de diferentes orígenes (Mesoamericano y Andino). Acta Agronómica, 65(4): 431-438, 2016. 
MELO, R. C. et al. Genetic variation in the trait root distribution over segregating generations of common bean. Euphytica, 207(3):665-674, 2016.

MENON, S. et al. Combining ability through line $x$ tester analysis for phenological seed yeld and oil traits in sunflower (Helianthus annuus L.). Euphytica, 204(1):199209, 2015.

MIGUEL, M. A. et al. Basal root whorl number: A modulator of phosphorus acquisition in common bean (Phaseolus vulgaris). Annals of botany, 112(6):973-982, 2013.

MOURA, L. M. et al. Combining ability of common bean parents in different seasons, locations and generations. Euphytica, 214(10):181, 2018.

MUKAMUHIRWA, F.; TUSIIME, G.; MUKANKUSI, M. C. Inheritance of high iron and zinc concentration in selected bean varieties. Euphytica, 205(2):349-360, 2015.

MUKANKUSI, C. et al. Genetic analysis of resistance to fusarium root rot in common bean. Euphytica, 182(1):11, 2011.

NIENHUIS, J.; SINGH, S. P. Genetics of seed yield and its components in common bean (Phaseolus vulgaris L.) of Middle-American Origin: I. General combining ability. Plant Breeding, 101(2):143-154, 1988.

OGHAN, H. A. et al. Identification of superior parents and hybrids for improving canola production under optimum and late sowing conditions. Euphytica, 214(6):1-16, 2018.

PANDOLFO, C. et al. Atlas climatológico digital do Estado de Santa Catarina. Florianópolis: Epagri, 2002. CD-Rom.

POLANIA, J. et al. Physiological traits associated with drought resistance in andean and mesoamerican genotypes of common bean (Phaseolus vulgaris L). Euphytica, 210(1):1729, 2016.

RAMALHO, M. A. P.; SANTOS, J. B. D.; ZIMMERMANN, M. J. $O$. Genética quantitativa em plantas autógamas: aplicações no melhoramento do feijoeiro. Goiânia: UFG, 1993. 271p.

RIBEIRO, T. et al. Evaluation of common bean genotypes for drought tolerance. Bragantia, 78(1):1-11, 2019.
RIESEBERG, L. H.; ARCHER, M. A.; WAYNE, R. K. Transgressive segregation, adaptation and speciation. Heredity, 83(4):363-372, 1999.

ROCHA, G. A. F.; PEREIRA, F. A. C.; VELLO, N. A. Potential of soybean crosses in early inbreeding generations for grain yield. Crop Breeding and Applied Biotechnology, 18(3): 267-275, 2018.

ROCHA, F. D. et al. Análise dialélica como ferramenta na seleção de genitores em feijão. Revista Ciência Agronômica, 45(1):74-81, 2014.

SANTOS, A. D. et al. Escolha de genitores de feijão-comum baseado na divergência genética. Agrarian, 8(29):235-245, 2015.

SINGH, S. P.; GEPTS, P.; DEBOUCK, D. G. Races of common bean (Phaseolus vulgaris, Fabaceae). Economic Botany, 4(53):379-396. 1991.

SINGH, J. et al. Maternal effects on seed and seedling phenotypes in reciprocal F1 hybrids of the common bean (Phaseolus vulgaris L.). Frontiers in Plant Science, 24(8):42, 2017.

VENCOVSKY, R.; BARRIGA, P. Genética biométrica no fitomelhoramento. Ribeirão Preto: Sociedade Brasileira de Genética, 1992. 496p

VELHO, L. P. et al. Root distribution and its association with bean growth habit. Anais da Academia Brasileira de Ciências, 90(2):1837-1844, 2018.

VIEIRA, C. O. Feijoeiro comum: Cultura, doenças e melhoramento. Viçosa: UFV, 1967. 220p.

TASISA, J. et al. Genetic control of inheritance of fruit quality attributes in tomato (Solanum lycopersicum). Agricultural Research, 7(2):120-128, 2018.

TOALDO, D. et al. Selection in early generations and the occurrence of heterosis for the character root distribution. Euphytica, 190(3):335-344, 2013.

ZHANG, Y.; KANG, M. S. DIALLEL-SAS: A SAS program for Griffing's diallel analyses. Agronomy Journal, 89(2):176182, 1997.

ZHANG, Y.; KANG, M. S.; LAMKEY, K. R. DIALLEL-SAS05: A comprehensive program for Griffing's and Gardner-Eberhart Analyses. Agronomy Journal, 97(4):1097-1106, 2005. 